Editorial

\title{
Open Data and Models for Energy and Environment
}

\author{
Benedetto Nastasi $^{1, *(\mathbb{D})}$, Massimiliano Manfren ${ }^{2}$ and Michel Noussan ${ }^{3}(\mathbb{D}$ \\ 1 Department of Planning, Design and Technology of Architecture, Sapienza University of Rome, \\ Via Flaminia 72, 00196 Rome, Italy \\ 2 Faculty of Engineering and Physical Sciences, University of Southampton, Boldrewood Innovation Campus, \\ Burgess Rd, Southampton SO16 7QF, UK; m.manfren@soton.ac.uk \\ 3 Fondazione Eni Enrico Mattei, Corso Magenta 63, 20123 Milano, Italy; michel.noussan@feem.it \\ * Correspondence: benedetto.nastasi@outlook.com
}

Citation: Nastasi, B.; Manfren, M.; Noussan, M. Open Data and Models for Energy and Environment. Energies 2021, 14, 4413. https://doi.org/ 10.3390/en14154413

Received: 29 May 2021

Accepted: 15 July 2021

Published: 22 July 2021

Publisher's Note: MDPI stays neutral with regard to jurisdictional claims in published maps and institutional affiliations.

Copyright: (c) 2021 by the authors. Licensee MDPI, Basel, Switzerland. This article is an open access article distributed under the terms and conditions of the Creative Commons Attribution (CC BY) license (https:// creativecommons.org/licenses/by/ $4.0 /)$.

\section{Overview of the Articles in This Special Issue}

An increasing number of data sources and models to handle them call for transparency and openness in assessing their goodness and practical use for people. The simplest and most robust tools to collect, process, and analyse data to offer solid data-based evidence for future projections in building and district and regional system planning are of interest. For this purpose, and following the success of the first Special Issue "Open Data and Energy Analytics", the Special Issue "Open Data and Models for Energy and Environment" has been launched, intended for energy engineers and planners. Among a very high number of submissions, 10 articles were selected for acceptance and published.

The first paper by Noussan and Neirotti [1] provides a quantification of the potential influence of different charging strategies on the average emission factor of the electricity supplied to electric vehicles. The next paper by Prina et al. [2] is related to the application of the EPLANOPT model to the Italian energy system, showing the difficulties to meet the Paris Agreement target of limiting the temperature increase to $1.5^{\circ} \mathrm{C}$.

The third paper in this special issue, by Neshat et al. [3], presents an optimization framework of a multi-mode wave energy converter to be tested in a small island in the west of Sicily, Italy, in the Mediterranean Sea. Cardone and Gargiulo [4], in the fourth paper of this special issue, describe a semiempirical model of a scroll compressor to predict the power consumption and the mass flow rate by considering leakages and mechanical losses. The next paper, by Amini et al. [5], performs a parametric study on wave energy converter layouts, investigating the distance influence and the effect of rotation regarding significant wave direction in each arrangement compared to the predefined layout. The sixth paper of this special issue, by Chiosa et al. [6], proposes an innovative anomaly detection and diagnosis methodology to automatically detect anomalous energy consumption in buildings, in addition to performing a diagnosis on the sub-loads that are responsible for anomalous patterns. In the next paper, Henrich et al. [7] analyse the impact of energy models in decision making processes for energy transitions in ten municipalities in the Netherlands. In the eight paper, Manfren et al. [8] review the role of energy modelling and analytics for energy transitions in the construction sector. Skeie and Gustavsen [9] investigate the use of geospatial data to improve the level of definition of weather variables used in data-driven building thermal performance characterization. Finally, in the tenth paper, Agostinelli et al. [10] illustrate the use of cyber-physical systems, Internet of things, and machine learning to achieve optimized energy management for a residential district in Rome.

Author Contributions: Conceptualization, B.N.; writing-original draft preparation, B.N., M.M. and M.N.; writing-review and editing, B.N., M.M. and M.N. All authors have read and agreed to the published version of the manuscript.

Funding: This research received no external funding. 
Conflicts of Interest: The authors declare no conflict of interests.

\section{References}

1. Noussan, M.; Neirotti, F. Cross-Country Comparison of Hourly Electricity Mixes for EV Charging Profiles. Energies 2020, 13, 2527. [CrossRef]

2. Prina, M.; Manzolini, G.; Moser, D.; Vaccaro, R.; Sparber, W. Multi-Objective Optimization Model EPLANopt for Energy Transition Analysis and Comparison with Climate-Change Scenarios. Energies 2020, 13, 3255. [CrossRef]

3. Neshat, M.; Sergiienko, N.; Amini, E.; Majidi Nezhad, M.; Astiaso Garcia, D.; Alexander, B.; Wagner, M. A New Bi-Level Optimisation Framework for Optimising a Multi-Mode Wave Energy Converter Design: A Case Study for the Marettimo Island, Mediterranean Sea. Energies 2020, 13, 5498. [CrossRef]

4. Cardone, M.; Gargiulo, B. Numerical Simulation and Experimental Validation of an Oil Free Scroll Compressor. Energies 2020, 13, 5863. [CrossRef]

5. Amini, E.; Golbaz, D.; Amini, F.; Majidi Nezhad, M.; Neshat, M.; Astiaso Garcia, D. A Parametric Study of Wave Energy Converter Layouts in Real Wave Models. Energies 2020, 13, 6095. [CrossRef]

6. Chiosa, R.; Piscitelli, M.; Capozzoli, A. A Data Analytics-Based Energy Information System (EIS) Tool to Perform Meter-Level Anomaly Detection and Diagnosis in Buildings. Energies 2021, 14, 237. [CrossRef]

7. Henrich, B.; Hoppe, T.; Diran, D.; Lukszo, Z. The Use of Energy Models in Local Heating Transition Decision Making: Insights from Ten Municipalities in The Netherlands. Energies 2021, 14, 423. [CrossRef]

8. Manfren, M.; Sibilla, M.; Tronchin, L. Energy Modelling and Analytics in the Built Environment-A Review of Their Role for Energy Transitions in the Construction Sector. Energies 2021, 14, 679. [CrossRef]

9. Skeie, K.; Gustavsen, A. Utilising Open Geospatial Data to Refine Weather Variables for Building Energy Performance EvaluationIncident Solar Radiation and Wind-Driven Infiltration Modelling. Energies 2021, 14, 802. [CrossRef]

10. Agostinelli, S.; Cumo, F.; Guidi, G.; Tomazzoli, C. Cyber-Physical Systems Improving Building Energy Management: Digital Twin and Artificial Intelligence. Energies 2021, 14, 2338. [CrossRef] 